\title{
Polyphasic Approach to the Classification and Identification of Gardnerella vaginalis and Unidentified Gardnerella vaginalis- Like Coryneforms Present in Bacterial Vaginosis
}

MARJAN VAN ESBROECK, ${ }^{1}$ PETER VANDAMME,${ }^{1,2}$ ENEVOLD FALSEN,${ }^{3}$ MARC VANCANNEYT, ${ }^{2}$ EDWARD MOORE, ${ }^{4}$ BRUNO POT, ${ }^{2,5}$ FRANÇOISE GAVINI, ${ }^{6}$ KAREL KERSTERS, ${ }^{2}$ AND HERMAN GOOSSENS ${ }^{1 *}$

Department of Microbiology, University Hospital UIA, Antwerp, ${ }^{1}$ and University of Ghent ${ }^{2}$ and Culture Collection of the Laboratorium voor Microbiologie Gent, ${ }^{5}$ Ghent, Belgium; Culture Collection, Department of Clinical Bacteriology, University of Göteborg, Göteborg, Sweden ${ }^{3}$; Department of Microbiology, National Research Center for Biotechnology, Braunschweig, Germany ${ }^{4}$; and Institut National de la Recherche Agronomique, Laboratoire d'Ecologie et de Physiologie du Système Digestif, Villeneuve d'Ascq, France ${ }^{6}$

\begin{abstract}
A taxonomic study of Gardnerella vaginalis and $G$. vaginalis-like coryneforms was performed in order to clarify the phylogenetic affiliation of these organisms and to improve future identification. We examined 50 strains by performing whole-cell protein and fatty acid analyses, a 16S rRNA sequence analysis, and an extensive phenotypic characterization analysis. The results of both chemotaxonomic techniques which we used divided the organisms into two main clusters, and the 16S rRNA sequence analysis revealed that the clusters represent different genera, which were easily distinguished by the results of classical phenotypic tests. The cluster I strains were identified as $G$. vaginalis, which was shown to be a close relative of the genus Bifidobacterium. An improved description of $G$. vaginalis is presented. The cluster II strains belong to or are closely related to Actinomyces turicensis.
\end{abstract}

Gardnerella vaginalis was first recognized by Leopold in 1953 and was said to resemble members of the genus Haemophilus (30). Both the pathogenic significance of $G$. vaginalis and the taxonomic status of this organism have been the subjects of debate. In 1955, Gardner and Dukes (16) named this organism Haemophilus vaginalis because it was a gram-negative, rodshaped bacterium that was successfully isolated on blood agar media but not on other agar media and it was believed to be responsible for a characteristic vaginal discharge. For a long time this organism was thought to be the etiological agent of bacterial vaginosis, but its role in this disease has been controversial, in part because of a lack of appropriate detection and identification methods for this fastidious organism. Now, it is assumed that bacterial vaginosis is also associated with other microorganisms, including Bacteroides spp., Mobiluncus spp., Mycoplasma hominis, Peptococcus spp., and Peptostreptococcus spp. $(3,22,26,36,43,44)$. Unlike other Haemophilus strains, $H$. vaginalis strains do not require hemin (X factor), NAD (V factor), or coenzyme-like substances for growth $(10,28,35)$. On the basis of a Gram stain reaction and cellular morphology similar to the Gram stain reaction and cellular morphology of members of the genus Corynebacterium, Zinneman and Turner (51) suggested that the organism should be removed from the genus Haemophilus and reclassified as Corynebacterium vaginale. Reyn et al. (39) studied the type strain of $H$. vaginalis by electron microscopy and concluded that the fine structure of its cell wall resembled that of a gram-positive bacterium and that it should probably be placed in the genus Corynebacterium or the genus Butyribacterium. These authors also indicated that this bacterium may be closely related to the genus Propionibacterium. In contrast, on the basis of the results of their electron microscopy studies Criswell et al. $(6,7)$ concluded that the fine

* Corresponding author. Mailing address: Department of Medical Microbiology, University Hospital UIA, Universiteitsplein 1, B-2610 Wilrijk, Belgium. Phone and Fax: 32.3.820.26.63. structure of the cell wall was more consistent with the fine structure of a gram-negative organism. However, on the basis of the results of a volatile acid production study, Moss and Dunkelberg (31) showed that $H$. vaginalis should not be placed in the genus Corynebacterium or the genus Butyribacterium. Also, it has been proposed that Lactobacillus is the proper genus for this organism $(1,15)$, but, as shown by Moss and Dunkelberg (31), acetic acid rather than lactic, butyric, or propionic acid is the principal fermentation end product, which makes placement in the genus Lactobacillus unsuitable.

In two more recent taxonomic papers published in 1980 (20, 37 ), the authors presented data obtained by a variety of biochemical methods and from DNA-DNA hybridization experiments and electron microscopy. The findings of these researchers revealed that $H$. vaginalis formed a good taxospecies that exhibited little or no similarity to established gram-positive or gram-negative genera. The need for a new genus designation led Greenwood and Pickett to propose the name Gardnerella vaginalis (20), a proposal supported by Piot et al. (37).

A reexamination of the cell wall ultrastructure of $G$. vaginalis ATCC $14018^{\mathrm{T}}(\mathrm{T}=$ type strain) and $G$. vaginalis clinical isolates led Sadhu et al. (40) to conclude that the cell walls of these organisms have a gram-positive type of organization and that the unusual thinness of the cell walls accounts for the gram-negative staining tendency of the organisms.

In this study, we used a polyphasic approach to clarify the phylogenetic affiliation of $G$. vaginalis and $G$. vaginalis-like coryneforms, which are found in the same niche.

\section{MATERIALS AND METHODS}

Bacterial strains. $G$. vaginalis reference strains, including type strain, CCUG 3717, were obtained from the Instituut voor Tropische Geneeskunde (ITG), Antwerp, Belgium, and from the Culture Collection of the University of Göteborg (CCUG), Göteborg, Sweden. In addition, field isolates were obtained from the ITG and CCUG and our collection. A total of 50 isolates were included in the study (Table 1), and some of these isolates were also used in several previous studies $(11-13,20,37)$. Bacteriological purity was checked by plating and exam- 
TABLE 1. Designations and sources of the strains used

\begin{tabular}{|c|c|c|}
\hline Strain $^{a}$ & Other designation $(\mathrm{s})^{a}$ & Source \\
\hline \multicolumn{3}{|l|}{ Cluster I strains } \\
\hline G. vaginalis ITG $887^{b}$ & PN Edmunds T145 & Human vagina, Edinburgh, United Kingdom \\
\hline G. vaginalis ITG $894^{b}$ & PN Edmunds T64 & Human vagina, Edinburgh, United Kingdom \\
\hline G. vaginalis ITG $895^{b}$ & LMG 14324, PN Edmunds T66 & Human vagina, Edinburgh, United Kingdom \\
\hline G. vaginalis ITG $897^{b}$ & PN Edmunds T34 & Human vagina, Edinburgh, United Kingdom \\
\hline G. vaginalis ITG $899^{b}$ & PE Pease 646 & \\
\hline G. vaginalis ITG $1044^{b . c}$ & CDC 1412, LMG 14325 & \\
\hline G. vaginalis ITG $1045^{b, c}$ & CDC 1413, LMG 14326 & \\
\hline G. vaginalis CCUG $3717^{\mathrm{T} b, c}$ & NCTC $10287^{\mathrm{T}}$, ATCC $14018^{\mathrm{T}}$, Dukes $594^{\mathrm{T}}$ & Human vagina, United States \\
\hline G. vaginalis CCUG $4121^{c}$ & Dunkelberg V32 & \\
\hline G. vaginalis CCUG $4123^{b, c}$ & VDRL CV 208 & Human vagina, United States \\
\hline G. vaginalis CCUG $10059^{b, c}$ & Pickett 37369 & Human vagina, United States \\
\hline G. vaginalis ITG 132 & & Human vagina, Antwerp, Belgium \\
\hline G. vaginalis ITG 145 & & Human vagina, Antwerp, Belgium \\
\hline G. vaginalis ITG 146 & & Human vagina, Antwerp, Belgium \\
\hline G. vaginalis ITG 286 & & Human vagina, Antwerp, Belgium \\
\hline G. vaginalis ITG 290 & & Human vagina, Antwerp, Belgium \\
\hline G. vaginalis ITG $293^{b}$ & & Human vagina, Antwerp, Belgium \\
\hline G. vaginalis ITG $300^{b}$ & & Human vagina, Antwerp, Belgium \\
\hline G. vaginalis ITG 802 & & Human vagina, Antwerp, Belgium \\
\hline G. vaginalis ITG $805^{b}$ & & Human vagina, Antwerp, Belgium \\
\hline G. vaginalis ITG 823 & & Human vagina, Antwerp, Belgium \\
\hline G. vaginalis ITG 828 & & Human vagina, Antwerp, Belgium \\
\hline G. vaginalis ITG 831 & & Human vagina, Antwerp, Belgium \\
\hline G. vaginalis ITG $833^{c}$ & LMG 14333, CCUG 32392 & Human vagina, Antwerp, Belgium \\
\hline G. vaginalis ITG 840 & & Human vagina, Antwerp, Belgium \\
\hline G. vaginalis ITG 879 & & Human vagina, Antwerp, Belgium \\
\hline G. vaginalis ITG 884 & & Human vagina, Antwerp, Belgium \\
\hline G. vaginalis CCUG $3990^{c}$ & & Human urine, Goteborg, Sweden \\
\hline G. vaginalis CCUG $7154^{c}$ & & Human ovarial abscess, Goteborg, Sweden \\
\hline G. vaginalis CCUG $7712^{c}$ & & Human amniotic fluid, Goteborg, Sweden \\
\hline G. vaginalis CCUG $7751^{c}$ & & Human urine, urosepsis, Goteborg, Sweden \\
\hline G. vaginalis CCUG $7921^{c}$ & & Human urine, Goteborg, Sweden \\
\hline G. vaginalis CCUG $11278 \mathrm{~A}^{c}$ & & Human urine, Goteborg, Sweden \\
\hline G. vaginalis CCUG $26939^{c}$ & & Human \\
\hline G. vaginalis CCUG $26996^{c}$ & & Human blood, Gavle, Sweden \\
\hline G. vaginalis CCUG $28963^{c}$ & & Human cervix, Boras, Sweden \\
\hline G. vaginalis CCUG $30587^{c}$ & & Human lung, Uppsala, Sweden \\
\hline G. vaginalis CCUG 30841 & & Human urine, Umea, Sweden \\
\hline G. vaginalis $\mathrm{VDAB} 2$ & & Human vagina, Antwerp, Belgium \\
\hline G. vaginalis PVR 101 & & Human vagina, Antwerp, Belgium \\
\hline \multicolumn{3}{|l|}{ Cluster II strains } \\
\hline G. vaginalis-like strain ITG $75^{b, c}$ & LMG 14329, CCUG 32388 & Human vagina, Antwerp, Belgium \\
\hline G. vaginalis-like strain ITG $131^{c}$ & LMG 14330, CCUG 32389 & Human vagina, Antwerp, Belgium \\
\hline G. vaginalis-like strain LMG $14331^{c}$ & ITG 137 , CCUG 32390 & Human vagina, Antwerp, Belgium \\
\hline G. vaginalis-like strain ITG $143^{b, c}$ & LMG 14736 , CCUG 33040 & Human vagina, Antwerp, Belgium \\
\hline G. vaginalis-like strain ITG $147^{b, c}$ & LMG 14735, CCUG 33039 & Human vagina, Antwerp, Belgium \\
\hline G. vaginalis-like strain ITG $284^{\text {b,c }}$ & LMG 14737, CCUG 33041 & Human vagina, Antwerp, Belgium \\
\hline G. vaginalis-like strain ITG $296^{c}$ & LMG 14332, CCUG 32391 & Human vagina, Antwerp, Belgium \\
\hline G. vaginalis-like strain ITG $806^{c}$ & LMG 14738, CCUG 33042 & Human vagina, Antwerp, Belgium \\
\hline G. vaginalis-like strain ITG $886^{c}$ & LMG 14734, CCUG 33038 & Human vagina, Antwerp, Belgium \\
\hline G. vaginalis-like strain ITG $900^{c}$ & LMG 14733, CCUG 33037 & Human penile ulcer, Antwerp, Belgium \\
\hline
\end{tabular}

${ }^{a}$ ATCC, American Type Culture Collection, Rockville, Md.; CCUG, Culture Collection of the University of Göteborg, Department of Clinical Bacteriology, University of Göteborg, Göteborg, Sweden; CDC, Centers for Disease Control and Prevention, Atlanta, Ga.; ITG, Instituut voor Tropische Geneeskunde, Antwerp, Belgium; LMG, Culture Collection of the Laboratorium Microbiologie Gent, University of Ghent, Ghent, Belgium; NCTC, National Collection of Type Cultures, London, England.

${ }_{b}^{b}$ Analyzed by using experimental API galleries that included tests for 59 peptidases, 10 esterases, and 20 glycosidases and for the presence of fructose-6-phosphate phosphoketolase.

${ }^{c}$ Examined by using the Rapid ID 32 Strep and API Coryne galleries.

ining living and Gram-stained cells. The organisms were grown on Columbia CNA agar (BBL, Becton Dickinson) supplemented with $6 \%$ fresh human blood, unless indicated otherwise, and were incubated aerobically at $37^{\circ} \mathrm{C}$ with $5 \% \mathrm{CO}_{2}$ enrichment.

Reference strains of all species of the genus Bifidobacterium were obtained from the Laboratorium Microbiologie Gent Culture Collection (LMG), Ghent Belgium. In addition, phenotypic data for 192 strains obtained from humans and belonging to 10 groups or species of the genus Bifidobacterium (previously classified on the basis of numerical analysis data $[2,17,18]$ ) were available for comparison.
PAGE of whole-cell proteins. All strains were grown for 4 days at $37^{\circ} \mathrm{C}$ on Columbia agar (23 g of Special Peptone, $1 \mathrm{~g}$ of corn starch, $5 \mathrm{~g}$ of sodium chloride, $0.3 \mathrm{~g}$ of cysteine $\mathrm{HCl}, 5 \mathrm{~g}$ of glucose, $20 \mathrm{~g}$ of agar, 1 liter of $\mathrm{H}_{2} \mathrm{O}$ ) supplemented with $5 \%$ horse blood and were incubated in an anaerobic atmosphere containing $5 \% \mathrm{CO}_{2}, 10 \% \mathrm{H}_{2}$, and $85 \% \mathrm{~N}_{2}$. Polyacrylamide gel electrophoresis (PAGE) of whole-cell proteins was performed as described by Pot et al. (38).

Bifidobacterium reference strains were grown for 2 days under the same conditions.

A densitometric analysis, normalization and interpolation of the protein pro- 


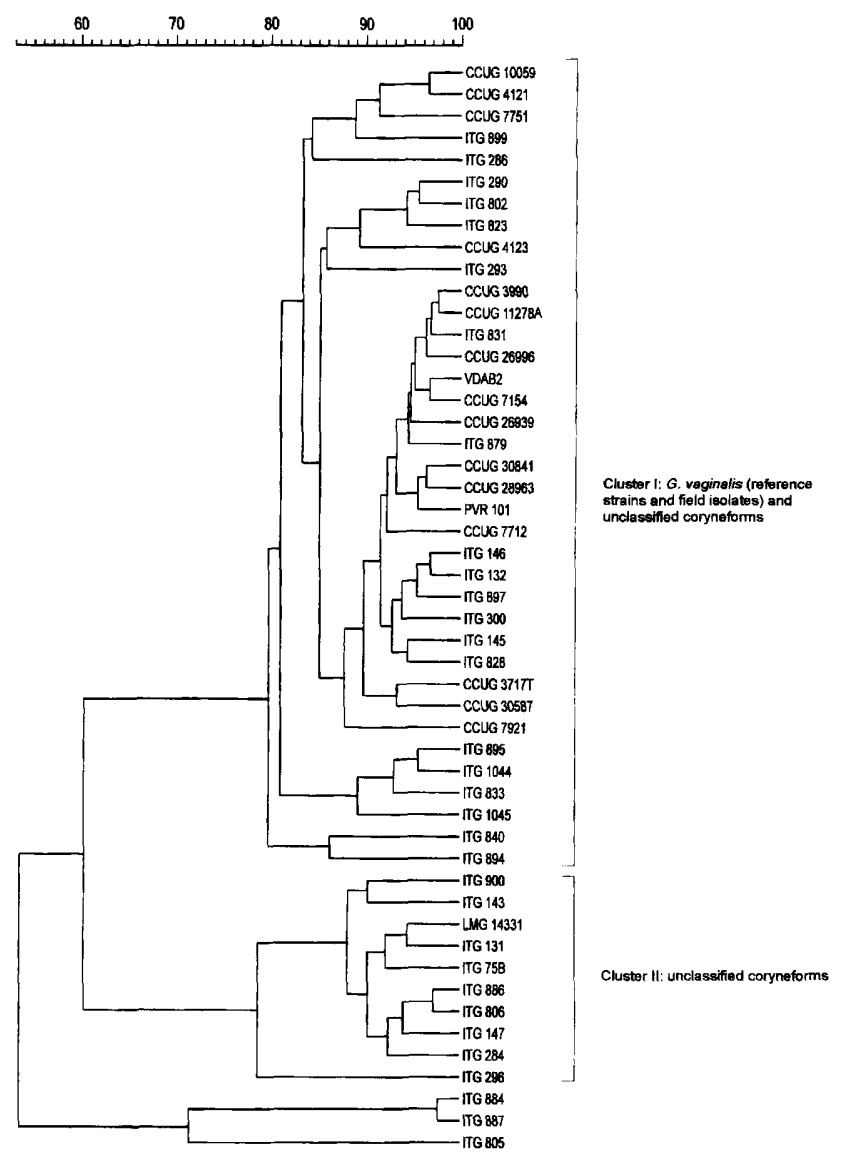

FIG. 1. Similarity dendrogram based on the protein patterns of $G$. vaginalis and $G$. vaginalis-like coryneform bacteria. Levels of correlation were expressed as percentages of similarity for convenience.

files, and a numerical analysis were performed by using the Gelcompar 3.1 software package (Applied Maths, Kortrijk, Belgium). Levels of correlation are presented below as percentages of similarity for convenience.

Cellular fatty acid analysis. After incubation for $48 \mathrm{~h}$, a loopful of cells was harvested, and the fatty acid methyl esters were extracted, separated, and identified as described previously (46).

Determination and analysis of $16 \mathrm{~S}$ rRNA gene sequences. Genomic DNA was prepared by the standard procedures described by Giesendorf et al. (19). The $16 S$ rRNA genes were amplified by PCR $(32,41)$, using a Perkin-Elmer Cetus GeneAmp PCR System 9600 apparatus. PCR was performed with forward primer $16 \mathrm{~F} 27$ (annealing at positions 8 to 27) and reverse primer 16R1525 (annealing at the complement of positions 1525 to 1541; Escherichia coli $16 \mathrm{~S}$ rRNA gene sequence numbering). The reaction conditions were the same as those described previously (25). PCR products were purified by using Centricon100 microconcentrators (Amicon $\mathrm{GmbH}$, Witten, Germany), and the sequence of the amplified $16 \mathrm{~S}$ ribosomal DNA was determined directly by using an Applied Biosystems model 373A DNA sequencer and the protocols of the manufacturer (Perkin-Elmer, Applied Biosystems GmbH, Weiterstadt, Germany) for Taq cycle sequencing with fluorescent dye-labeled dideoxynucleotides. The sequencing primers which we used have been described previously (27).

The sequence data which we obtained were aligned with previously described 16 S rRNA (and rRNA gene) sequences $(9,34)$ by using conserved regions and secondary-structure characteristics as references $(21,48)$. Sequence similarity values and evolutionary distances, which incorporated a correction factor (24) for reverse mutations, were calculated for masked (27) and unmasked sequence pair comparisons by using unambiguous nucleotide positions.

Phenotypic characterization. A total of 27 strains, including 17 cluster I strains (see below) which represented the diversity of this cluster, as determined by cellular protein and fatty acid analyses, and all 10 cluster II strains (see below), were examined by using Rapid ID 32 Strep and API Coryne galleries (bioMérieux, La Balme-les-Grottes, Montalieu-Vercieu, France), as described by the manufacturer. In addition, 13 cluster I strains and all of the cluster II strains were analyzed by using experimental API galleries that included tests for 59 peptidases, 10 esterases (tests performed with all strains except strains LMG 14331 and ITG 131), and 20 glycosidases (tests performed with all strains except strains LMG 14331, ITG 131, ITG 296, ITG 806, ITG 886, and ITG 900). The presence of fructose-6-phosphate phosphoketolase activity (42) in the same 13 cluster I strains and all of the cluster II strains was verified.

Nucleotide sequence accession number. The $16 \mathrm{~S}$ ribosomal DNA sequence of strain LMG 14331, a representative of protein electrophoretic cluster II (see below), has been deposited in the GenBank database under accession number X87133.

\section{RESULTS}

SDS-PAGE of whole-cell proteins. All of the strains listed in Table 1 were examined by sodium dodecyl sulfate (SDS)PAGE. Duplicate protein extracts of several strains were prepared to check the reproducibility of the growth conditions and the preparation of the extracts. The levels of correlation between duplicate protein patterns were more than $93 \%$ (data not shown).

The dendrogram obtained after we performed a numerical

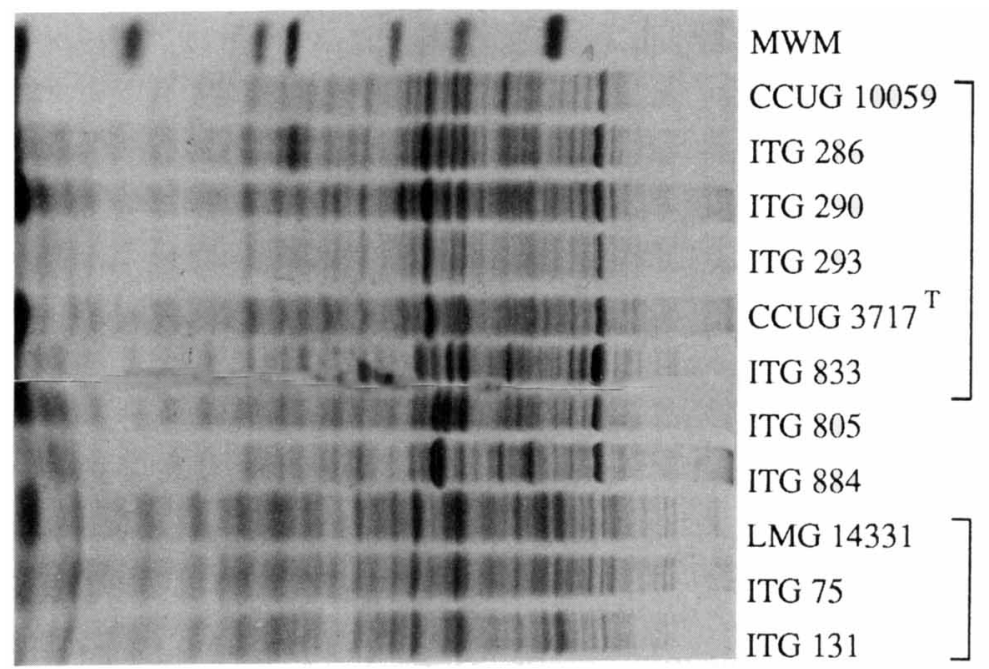

Cluster I: G. vaginalis and unclassified coryneforms

Cluster II: unclassified coryneforms

FIG. 2. Electrophoretic protein profiles of representative strains belonging to both electrophoretic clusters and of two aberrant strains ( $G$. vaginalis ITG 805 and ITG 884). The following molecular weight markers were used (track MWM, from left to right): trypsin inhibitor (molecular weight, 20,100$)$, trypsinogen $(24,000)$, carbonic anhydrase $(29,000)$, glyceraldehyde-3-phosphate dehydrogenase $(36,000)$, egg albumin $(45,000)$, and bovine albumin $(66,000)$. 
TABLE 2. Mean fatty acid compositions of the strains studied ${ }^{a}$

\begin{tabular}{lccccccccc}
\hline & & \multicolumn{9}{c}{$\%$ of: } \\
\cline { 3 - 9 } Cluster & No. of strains & $14: 0$ & $16: 1 \omega 7 \mathrm{c}$ & $16: 0$ & $18: 2 \omega 6,9 \mathrm{c}$ & $18: 1 \omega 9 \mathrm{c}$ & $\begin{array}{c}\text { Summed } \\
\text { feature } 7^{b}\end{array}$ & $18: 0$ & $19: 0$ iso \\
\hline I & 40 & $6.9 \pm 1.5$ & $3.0 \pm 0.9$ & $36.6 \pm 2.9$ & $4.8 \pm 1.3$ & $35.2 \pm 2.2$ & $2.5 \pm 2.0$ & $9.2 \pm 1.4$ & $\mathrm{Tr}$ \\
II & 10 & $4.6 \pm 0.4$ & $6.2 \pm 0.5$ & $23.5 \pm 2.2$ & $8.0 \pm 1.5$ & $44.3 \pm 3.3$ & $4.4 \pm 2.3$ & $3.8 \pm 0.5$ & $1.1 \pm 0.6$ \\
\hline
\end{tabular}

${ }^{a}$ Fatty acids that were present at concentrations of less than $1 \%$ in both groups are not shown, which explains why the values do not add up to $100 \%$.

${ }^{b}$ Summed feature 7 comprises 18:1 $\omega 7 \mathrm{c}, 18: 1 \omega 9 \mathrm{t}$, or $18: 1 \omega 12 \mathrm{t}$ or any combination of these isomers.

analysis with all of the protein patterns is shown in Fig. 1. Figure 2 shows a representative selection of the patterns examined. In the numerical analysis, two major clusters were differentiated. In addition, two strains that had very similar protein patterns (ITG 884 and ITG 887) and strain ITG 805 occupied distinct positions on the dendrogram. Cluster I contained 37 strains, including the type and reference strains of $G$. vaginalis, several field isolates identified as $G$. vaginalis on the basis of the biochemical characteristics, and several strains received as unclassified $G$. vaginalis-like coryneforms, that grouped above a correlation level of $79 \%$. The overall protein profiles of these strains were very similar, except in the 36,000 to 45,000 -molecular-weight region (Fig. 2); in this region there were one to four dense protein bands whose positions were highly variable. The protein patterns of strains ITG 805 , ITG
884 (Fig. 2), and ITG 887 differed in other ways, although the overall patterns were fairly similar. Cluster II contained 10 unclassified $G$. vaginalis-like coryneforms that grouped above a correlation level of $78 \%$.

Our numerical analysis of these protein patterns and the patterns of Bifidobacterium reference strains revealed that cluster I and II strains and strains ITG 884, ITG 887, and ITG 805 differed from the taxa in the genus Bifidobacterium that have been described (data not shown).

Fatty acid methyl ester composition. A numerical analysis of the fatty acid components of the 50 strains which we examined revealed two subgroups (data not shown). The first subgroup contained all of the protein electrophoretic cluster I strains and aberrant isolates ITG 805 , ITG 884 , and ITG 887 ; the

TABLE 3. Levels of unmasked 16S rRNA gene sequence similarity between G. vaginalis-like strain LMG 14331 or $G$. vaginalis ATCC $14018^{\mathrm{T}}$ and representative reference organisms

\begin{tabular}{|c|c|c|c|c|}
\hline Taxon & Strain $^{a}$ & $\begin{array}{l}\text { Nucleotide sequence } \\
\text { accession no. }\end{array}$ & $\begin{array}{l}\text { \% Sequence similarity with } \\
\text { G. vaginalis-like strain LMG } 14331\end{array}$ & $\begin{array}{l}\% \text { Sequence similarity with } \\
\text { G. vaginalis ATCC } 14018^{\mathrm{T}}\end{array}$ \\
\hline Actinomyces bovis & DSM $43014^{\mathrm{T}}$ & X53224 & 87.6 & 83.0 \\
\hline Actinomyces radingae & DSM $9169^{\mathrm{T}}$ & X78719 & 90.9 & 83.1 \\
\hline Actinomyces turicensis & DSM $9168^{\mathrm{T}}$ & X78720 & 98.4 & 82.5 \\
\hline Actinomyces pyogenes & ATCC $19411^{\mathrm{T}}$ & M29522 & 86.9 & 83.2 \\
\hline Actinomyces odontolyticus & DSM 43331 & X53227 & 94.1 & 83.5 \\
\hline Actinomyces hyovaginalis & & X69616 & 94.7 & 82.6 \\
\hline Aeromicrobium erythreum & NRRL B-3381 & $-b$ & 82.6 & 82.7 \\
\hline Arcanobacterium haemolyticum & & X73952 & 87.4 & 82.7 \\
\hline Arthrobacter globiformis & DSM $20124^{\mathrm{T}}$ & - & 85.3 & 84.3 \\
\hline Bifidobacterium bifidum & ATCC $29521^{\mathrm{T}}$ & - & 81.5 & 93.1 \\
\hline Bifidobacterium dentium & ATCC 15423 & - & 80.9 & 92.4 \\
\hline Bifidobacterium longum & ATCC $15707^{\mathrm{T}}$ & - & 80.3 & 92.6 \\
\hline Corynebacterium xerosis & ATCC $373^{T}$ & - & 84.1 & 82.8 \\
\hline Dermatophilus congolensis & ATCC $14637^{\mathrm{T}}$ & - & 86.6 & 84.1 \\
\hline Gardnerella vaginalis & ATCC $14018^{\mathrm{T}}$ & - & 84.9 & \\
\hline Gordona terrae & DSM $43249^{\mathrm{T}}$ & X79286 & 84.4 & 82.4 \\
\hline Micrococcus luteus & ATCC $381^{\mathrm{T}}$ & - & 85.5 & 84.1 \\
\hline Mycobacterium tuberculosis & NCTC 7416 & X58890 & 83.0 & 81.5 \\
\hline Nocardia asteroides & DSM $43757^{\mathrm{T}}$ & X80606 & 84.1 & 82.7 \\
\hline Nocardioides simplex & NCIMB $8929^{\mathrm{T}}$ & X53213 & 82.2 & 81.4 \\
\hline Propionibacterium freudenreichii & DSM $20271^{\mathrm{T}}$ & - & 82.0 & 82.5 \\
\hline Pseudonocardia thermophilus & ATCC $19285^{\mathrm{T}}$ & X53195 & 85.1 & 83.2 \\
\hline Rhodococcus globerulus & NCIMB $12315^{\mathrm{T}}$ & X77779 & 83.2 & 81.6 \\
\hline Rhodococcus rhodochrous & DSM $43241^{\mathrm{T}}$ & X79288 & 85.6 & 84.0 \\
\hline Rothia dentocariosa & ATCC $17931^{\mathrm{T}}$ & - & 85.3 & 83.9 \\
\hline Saccharothrix australiensis & DSM $43800^{\mathrm{T}}$ & X53193 & 83.0 & 81.9 \\
\hline Streptomyces albus & DSM 40313 & X53163 & 81.2 & 79.5 \\
\hline Streptomyces phosalacineus & DSM $43860^{\mathrm{T}}$ & M55223 & 81.9 & 80.7 \\
\hline Terrabacter tumescens & NCIMB $8914^{\mathrm{T}}$ & X53215 & 85.1 & 83.5 \\
\hline Tsukamurella paurometabolum & NCTC $10741^{\mathrm{T}}$ & - & 84.6 & 82.1 \\
\hline Bacillus licheniformis & DSM $13^{\mathrm{T}}$ & X68416 & 74.4 & 76.3 \\
\hline Fusobacterium nucleatum & ATCC $25586^{\mathrm{T}}$ & X55401 & 73.6 & 73.7 \\
\hline
\end{tabular}

\footnotetext{
${ }^{a}$ DSM, Deutsche Sammlung von Mikroorganismen und Zellkulturen, Braunschweig, Germany; NCIMB, National Collection of Industrial and Marine Bacteria,
} Aberdeen, Scotland. For other abbreviations see Table 1, footnote $a$.

${ }^{b}$-, sequence obtained from the Ribosomal RNA Database Project database (34). 
second subgroup contained all of the protein electrophoretic cluster II strains (see above).

The fatty acid components of the two subgroups are shown in Table 2. The predominant fatty acids in all of the strains studied are 14:0,16:1 $\omega 7 \mathrm{c}, 16: 0,18: 1 \omega 9 \mathrm{c}, 18: 0$, summed feature 6, and summed feature 7. Quantitative differences readily allow differentiation of the two subgroups.

16S rRNA sequence analysis. PCR amplification of the $16 \mathrm{~S}$ rRNA genes between the nucleotides at positions 28 and 1525 allowed us to determine the nucleotides at 1,474 positions, which account for approximately $96 \%$ of the complete gene sequence (estimated by comparison with the 16S rRNA gene sequence of $E$. coli). Masked sequence comparisons (involving 1,349 nucleotide positions) of the $16 \mathrm{~S}$ ribosomal DNAs revealed that strain LMG 14331 clustered with the gram-positive bacteria with high genomic DNA G $+C$ contents (47) and most closely with species belonging to the genus Actinomyces (data not shown). Table 3 shows the results of unmasked comparisons between the sequence of strain LMG 14331 or G. vaginalis ATCC $14018^{T}$ and the sequences of representative reference strains belonging to the gram-positive high- $\mathrm{G}+\mathrm{C}$-content species. The highest level of sequence similarity (98.4\%) was the level of similarity between LMG 14331 and Actinomyces turicensis. Analyses of partial sequences (analyses of about $30 \%$ of the complete gene, including the most variable regions of the $16 \mathrm{~S}$ ribosomal DNA gene of $G$. vaginalis CCUG $3717^{\mathrm{T}}$ ) were performed to verify the sequence of $G$. vaginalis ATCC $14018^{\mathrm{T}}$ rRNA in the Ribosomal RNA Database Project database (34). The sequences which we determined corresponded completely with the sequence present in the Ribosomal RNA Database Project database, and therefore the complete Ribosomal RNA Database Project sequence was used for phylogenetic analyses.

Phenotypic characterization. The following tests were negative for all of the strains examined: arginine dihydrolase, $N$-acetyl- $\beta$ glucosaminidase, urease, esculin hydrolysis, catalase, $\gamma$-glutamyltransferase, $N$-carboxybenzoxy-glycyl-glycyl-arginine arylamidase, pyroglu-tamic acid arylamidase, glycyl-tryptophan arylamidase, $\alpha$-L-aspar-tyl-L-alanine arylamidase, $\alpha$-L-aspartyl-L-arginine arylamidase, $\alpha$-L-glutamyl- $\alpha$-L-glutamine arylamidase, L-leucyl-L-leucyl-L-valyl-L-tyrosyl-L-serine arylamidase, $N$-benzoyl-L-alanine-4methoxyarylamidase, $N$-carboxybenzoxy-glycyl-L-arginine arylamidase, $N$-acetyl-glycyl-L-lysine arylamidase, $\alpha$-D-galactosidase, phospho- $\beta$-D-galactosidase, $\alpha$-L-arabinosidase, $\beta$-D-glucosidase, $\beta$-D-galacturonohydrolase, $\beta$-D-glucuronidase, $\beta$-maltosidase, $\alpha$-L-fucosidase, $\beta$-D-fucosidase, $\beta$-L-fucosidase, $\beta$-D-lactosidase, $\beta$-D-mannosidase, $\alpha$-D-xylosidase, $\beta$-D-xylosidase, esterase $C_{6}$, $\mathrm{C}_{16}$, and $\mathrm{C}_{18}$, nitrate reduction, hydrolysis of gelatin, acetoin production, and acidification of mannitol, sorbitol, lactose, trehalose, raffinose, melibiose, melezitose, D-arabitol, methyl- $\beta$ D-glucopyranoside, tagatose, and cyclodextrin.

The following tests were positive for all of the strains examined: pyrazinamidase, alanyl-phenylalanyl-proline arylamidase, L-tyrosine arylamidase, L-phenylalanine arylamidase, L-lysine arylamidase, L-hydroxyproline arylamidase, L-histidine arylamidase, glycine arylamidase, L-arginine arylamidase, L-alanine arylamidase, glycyl-proline arylamidase, leucyl-glycine arylamidase, L-ornithine arylamidase, L-proline arylamidase, $\mathrm{L}$-serine arylamidase, L-threonine arylamidase, $\beta$-alanine arylamidase, L-lysyl-L-alanine arylamidase, L-lysyl-L-lysine arylamidase, L-phenylalanyl-L-proline arylamidase, L-phenylalanyl-L-prolyl-L-alanine arylamidase, $\alpha$ maltosidase, and acidification of maltose and ribose.

The remaining test results are shown in Table 4. Differences in test results between the Rapid ID 32 Strep and API Coryne galleries were found only for the presence of alkaline phosphatase in cluster I strains.

\section{DISCUSSION}

The phylogenetic positions of bacteria identified previously as $G$. vaginalis and other unidentified $G$. vaginalis-like coryneforms (37) isolated from bacterial vaginosis specimens have been controversial and unsettled for many years. In order to clarify the situation, we performed an integrated study in which we determined the genotypic and phenotypic characteristics of $50 G$. vaginalis and $G$. vaginalis-like strains.

Strains studied. The strains which we studied included reference strains of $G$. vaginalis and field isolates which were identified by biochemical tests as $G$. vaginalis or unidentified $G$. vaginalis-like coryneforms. Among the latter strains were 26 isolates which belonged to two biochemical subgroups according to the data of Piot et al. (37). Our data (see below) allowed us to subdivide our collection of strains into two main subgroups, which were designated cluster I and cluster II.

There were some differences between our results and the results of Piot et al. (37). Piot et al. described strains ITG 132, ITG 145, ITG 146, ITG 286, ITG 300, ITG 802, ITG 833, ITG 887 , and ITG 899 as members of the cluster containing the unclassified catalase-negative coryneforms, while our results showed that these strains are closely related to the G. vaginalis type strain (Fig. 1 and Table 2). These apparently contradictory results were confirmed after we repeated our analyses of these strains by starting with fresh cultures. Furthermore, the results of the fatty acid and protein electrophoresis analyses pointed toward the same conclusions. One of these strains, ITG 833 , was included in the phenotypic analyses and produced a typical $G$. vaginalis pattern. The results of our various approaches confirmed each other, and it has been established with several taxa that high levels of similarity in whole-cell protein contents correlate with high levels of DNA-DNA homology (5). Our results therefore suggest that the nine isolates listed above are genuine $G$. vaginalis strains. Our results also revealed that the 10 cluster II strains from a homogeneous taxon, while the hybridization experiments of Piot et al. (37) revealed low levels of DNA homology for some of these strains. We again found that the results of all of our experiments correlated with each other and indicated that the 10 isolates examined form a homogeneous species. These findings indicate that the identities of some of the ITG isolates might be questioned as these isolates do not seem to correspond to the isolates studied by Piot et al. (37).

Taxonomic status of cluster I strains. Despite the considerable variability in a dense protein band region, 37 isolates produced very similar overall protein patterns. Ten $G$. vaginalis reference strains, including the type strain, belong to this cluster, and therefore, given the correlation between the similarity of whole-cell protein patterns and DNA homology values (5), we consider all of these isolates genuine $G$. vaginalis strains. Reference strain ITG 887 and two other isolates produced aberrant protein patterns. However, the overall protein patterns of these organisms shared many protein bands with the patterns of the $G$. vaginalis strains, and we found no differences when the same isolates were examined in the fatty acid analysis or by a battery of biochemical tests. Therefore, we consider all three of these strains protein electrophoretically aberrant $G$. vaginalis strains. A salient feature of all of the cluster I strains is the extreme variability in the dense protein bands in the 36,000 - to 45,000 -molecular-weight range (Fig. 2), a finding which has been reported by other workers (4).

The cellular fatty acid profiles of these strains contained a number of unidentified peaks for fatty acids which could not be differentiated under the gas chromatographic conditions which we used. Summed feature 6 comprises fatty acid $18: 2 \omega 6,9 \mathrm{c}$ or 
TABLE 4. Phenotypic differences between $G$. vaginalis and $G$. vaginalis-like bacteria

\begin{tabular}{|c|c|c|c|c|}
\hline \multirow[b]{2}{*}{ Test } & \multicolumn{2}{|c|}{ G. vaginalis } & \multicolumn{2}{|c|}{ G. vaginalis-like bacteria } \\
\hline & $\begin{array}{c}\% \text { of strains } \\
\text { positive }(n=17)\end{array}$ & $\begin{array}{l}\text { Reaction of strain } \\
\text { CCUG } 3717^{\mathrm{T}}\end{array}$ & $\begin{array}{c}\% \text { of strains } \\
\text { positive }(n=10)\end{array}$ & $\begin{array}{l}\text { Reaction of strain } \\
\text { LMG } 14331\end{array}$ \\
\hline Fructose-6-phosphate phosphoketolase & 100 & $+^{a}$ & 0 & - \\
\hline$\beta$-D-Galactosidase & 71 & + & 0 & - \\
\hline$\alpha$-D-Glucosidase & 77 & + & 100 & + \\
\hline Alkaline phosphatase (Rapid ID 32 Strep) & 76 & + & 0 & - \\
\hline Alkaline phosphatase (API Coryne) & 0 & - & 0 & - \\
\hline Hydrolysis of hippurate & 88 & + & 90 & + \\
\hline Acidification of glucose & 82 & ND & 100 & + \\
\hline Acidification of glycogen & 63 & + & 0 & - \\
\hline Acidification of pullulan & 59 & + & 0 & - \\
\hline Acidification of saccharose & 0 & - & 100 & + \\
\hline Acidification of L-arabinose & 12 & - & 10 & - \\
\hline Acidification of xylose & 0 & - & 100 & + \\
\hline L-Pyrrolidone arylamidase & 92 & + & 40 & - \\
\hline L-Aspartate arylamidase & 77 & - & 80 & - \\
\hline$N$-Benzoyl-leucine arylamidase & 15 & + & 33 & - \\
\hline$S$-Benzyl-cysteine arylamidase & 100 & + & 33 & - \\
\hline Methionine arylamidase & 92 & + & 11 & - \\
\hline Glycyl-glycine arylamidase & 23 & + & 33 & - \\
\hline Glycyl-phenylalanine arylamidase & 69 & + & 33 & - \\
\hline L-Seryl-tyrosine arylamidase & 92 & + & 80 & - \\
\hline $\mathrm{N}$-Carboxybenzoxy-arginine-4-methoxyarylamidase & 62 & + & 30 & - \\
\hline L-Glutamine arylamidase & 85 & + & 20 & - \\
\hline$\alpha$-L-Glutamate arylamidase & 100 & + & 20 & - \\
\hline L-Isoleucine arylamidase & 54 & - & 10 & - \\
\hline L-Tryptophan arylamidase & 77 & + & 80 & + \\
\hline L-Alanyl-L-arginine arylamidase & 69 & + & 60 & - \\
\hline L-Alanyl-L-phenylalanyl-L-proline arylamidase & 62 & + & 100 & + \\
\hline L-Alanyl-L-phenylalanyl-L-prolyl-L-alanine arylamidase & 85 & + & 50 & - \\
\hline L-Arginyl-L-arginine arylamidase & 15 & + & 10 & - \\
\hline$\alpha$-L-Glutamyl-L-histidine arylamidase & 92 & + & 0 & - \\
\hline Glycyl-L-alanine arylamidase & 23 & + & 80 & + \\
\hline Glycyl-L-arginine arylamidase & 100 & + & 60 & - \\
\hline Glycyl-L-tryptophan arylamidase & 23 & + & 0 & - \\
\hline L-Histidyl-L-leucyl-L-histidine arylamidase & 100 & + & 20 & - \\
\hline L-Histidyl-L-serine arylamidase & 100 & + & 20 & - \\
\hline L-Leucyl-L-alanine arylamidase & 100 & + & 40 & + \\
\hline L-Phenylalanyl-L-arginine arylamidase & 92 & + & 20 & - \\
\hline L-Prolyl-L-arginine arylamidase & 100 & + & 70 & + \\
\hline L-Seryl-L-methionine arylamidase & 69 & + & 10 & - \\
\hline L-Valyl-L-tyrosyl-L-serine arylamidase & 85 & - & 0 & - \\
\hline $\mathrm{N}$-Carboxybenzoxy-arginyl-4-methoxyarylamidase & 38 & - & 20 & - \\
\hline L-Histidyl-L-phenylalanine arylamidase & 38 & - & 0 & - \\
\hline L-Lysyl-L-serine-4-methoxyarylamidase & 92 & + & 0 & - \\
\hline$N$-Acetyl- $\alpha$-D-glucosaminidase & 92 & + & 25 & ND \\
\hline$\alpha$-D-Mannosidase & 85 & + & 25 & ND \\
\hline Esterase $\mathrm{C}_{4}$ & 15 & - & 13 & ND \\
\hline Esterase $\mathrm{C}_{5}$ & 15 & - & 13 & ND \\
\hline Esterase $\mathrm{C}_{8}$ & 46 & - & 25 & ND \\
\hline Esterase $\mathrm{C}_{9}$ & 62 & - & 13 & ND \\
\hline Esterase $C_{10}$ & 85 & + & 25 & ND \\
\hline Esterase $C_{12}$ & 46 & - & 0 & ND \\
\hline Esterase $C_{14}$ & 23 & - & 0 & ND \\
\hline
\end{tabular}

${ }^{a}+$, positive;,- negative; ND, not determined.

18:0 ante or both. Because G. vaginalis lacks branched-chain fatty acids and the presence of 18:2 has been described previously $(8,23,31)$, we assume that the peak corresponding to summed feature 6 contains only 18:2 $\omega 6,9 \mathrm{c}$. Summed feature 7 comprises one or more isomers of 18:1 (Table 2) and was detected in all of the strains examined.

The mean fatty acid composition of the cluster I strains (about 7\% 14:0, about 3\% 16:1 $\omega 7 \mathrm{c}$, about 37\% 16:0, about $35 \% 18: 1 \omega 9 \mathrm{c}$, about 9\% 18:0, about 5\% 18:2 $\omega 6,9 \mathrm{c}$, and about
$2 \%$ summed feature 7) corresponds well to the results of O’Donnell et al. (33) and Csángó et al. (8).

The results of our analysis of the variable regions of the $16 \mathrm{~S}$ ribosomal DNA of $G$. vaginalis CCUG $3717^{\mathrm{T}}$ confirmed the sequence of another subculture of the type strain in the Ribosomal RNA Database Project database. An extensive comparison of the latter sequence with the sequences of other grampositive bacteria having high $\mathrm{G}+\mathrm{C}$ contents revealed that $G$. vaginalis is closely related to the genus Bifidobacterium (level 
of similarity with the type species, Bifidobacterium bifidum, 93.1\%). The results of subsequent phenotypic analyses indicated that $G$. vaginalis exhibits fructose-6-phosphate phosphoketolase activity, a feature which was assumed to be specific to the genus Bifidobacterium (42). However, several investigators have reported that the DNA base ratio of $G$. vaginalis is approximately $42 \mathrm{~mol} \%(23,29,37,45)$, whereas the $\mathrm{G}+\mathrm{C}$ content of Bifidobacterium DNAs vary from 55 to 67 mol\% (2). This difference in DNA base ratio is far too large to consider $G$. vaginalis a Bifidobacterium species. The results of a comparison of the whole-cell protein patterns of $G$. vaginalis and Bifidobacterium reference strains revealed a number of similarities in the overall protein profiles but also allowed us to differentiate $G$. vaginalis from all Bifidobacterium species that have been described (data not shown). A comparison of the phenotypic characteristics of $G$. vaginalis and Bifidobacterium species $(2,17,18)$ yielded several differential characteristics; however, these findings are beyond the scope of this paper. The various phenotypic analyses which we performed did not yield genus-specific characteristics which could be used to separate the two genera.

We concluded that the two organisms represent distinct genera belonging to a single phylogenetic lineage, and therefore our data supported the proposal of Greenwood and Pickett (20) and Piot et al. (37).

The following characteristics can be added to the description of $G$. vaginalis given by Greenwood and Pickett (20): positive for fructose-6-phosphate phosphoketolase, L-tyrosine arylamidase, L-pyrrolidone arylamidase, L-phenylalanine arylamidase, L-lysine arylamidase, L-hydroxyproline arylamidase, L-histidine arylamidase, glycine arylamidase, L-arginine arylamidase, Lalanine arylamidase, $S$-benzyl-cysteine arylamidase, methionine arylamidase, glycyl-proline arylamidase, leucyl-glycine arylamidase, L-seryl-tyrosine arylamidase, $\alpha$-L-glutamate arylamidase, L-ornithine arylamidase, L-proline arylamidase, $\mathrm{L}$-serine arylamidase, $\mathrm{L}$-threonine arylamidase, $\beta$-alanine arylamidase, $\alpha$-L-glutamyl-L-histidine arylamidase, glycyl-L-arginine arylamidase, L-histidyl-L-leucyl-L-histidine arylamidase, Lhistidyl-L-serine arylamidase, L-leucyl-L-alanine arylamidase, L-lysyl-L-lysine arylamidase, L-phenylalanyl-L-arginine arylamidase, L-phenylalanyl-L-proline arylamidase, L-phenylalanyl-Lprolyl-L-alanine arylamidase, L-prolyl-L-arginine arylamidase, L-lysyl-L-serine-4-methoxyarylamidase, $\beta$-D-galactosidase, $\alpha$-Dglucosidase, $\alpha$-maltosidase, $N$-acetyl- $\alpha$-D-glucosaminidase, alanyl-phenylalanyl-proline arylamidase, and pyrazinamidase; and negative for arginine dihydrolase, $N$-acetyl- $\beta$-glucosaminidase, esculin hydrolysis, $\gamma$-glutamyltransferase, $N$-carboxybenzoxyglycyl-glycyl-arginine arylamidase, pyroglutamic acid arylamidase, glycyl-tryptophan arylamidase, $\alpha$-L-aspartyl-L-alanine arylamidase, $\alpha$-L-aspartyl-L-arginine arylamidase, $\alpha$-L-glutamyl$\alpha$-L-glutamine arylamidase, $N$-benzoyl-L-alanine-4-methoxyarylamidase, $N$-carboxybenzoxy-glycyl-L-arginine arylamidase, $N$-acetyl-glycyl-L-lysine arylamidase, $\alpha$-D-galactosidase, phospho- $\beta$-D-galactosidase, $\alpha$-L-arabinosidase, $\beta$-D-glucosidase, $\beta$-D-galacturonohydrolase, $\beta$-D-glucuronidase, $\beta$-maltosidase, $\alpha$-L-fucosidase, $\beta$-D-fucosidase, $\beta$-L-fucosidase, $\beta$-D-lactosidase, $\beta$-D-mannosidase, $\alpha$-D-xylosidase, $\beta$-D-xylosidase, esterase $\mathrm{C}_{6}, \mathrm{C}_{16}$, and $\mathrm{C}_{18}$, nitrate reduction, hydrolysis of gelatin, acetoin production, and acidification of lactose, trehalose, raffinose, melibiose, melezitose, saccharose, $D$-arabitol, methyl- $\beta$ D-glucopyranoside, tagatose, and xylose.

Taxonomic status of cluster II strains. On the basis of the results of SDS-PAGE and fatty acid analyses, the 10 cluster II strains formed a homogeneous group. Sequence comparisons of the $16 \mathrm{~S}$ ribosomal DNAs revealed a level of similarity of 98.4\% between strain LMG 14331 and the type strain of $A$. turicensis, which is within the range of values for a single species (14). The latter organism is a facultatively anaerobic, gram-positive, asporogenous, rod-shaped bacterium that has succinic and lactic acids as its main metabolic products and a DNA base composition of $57 \mathrm{~mol} \% \mathrm{G}+\mathrm{C}$. The two strains described as $A$. turicensis were isolated from mixed infections with anaerobes in a perianal abscess and pleural empyema (49, 50 ). When the phenotypic characteristics of cluster II and $A$. turicensis strains were compared, 16 common features were detected. We found differences only in $\alpha$-L-fucosidase activity and in acidification of L-arabinose, lactose, mannitol, melezitose, melibiose, raffinose, and trehalose (in our study, 0 to $10 \%$ of the cluster II strains acidified these compounds, compared with one of the $A$. turicensis strains). Esterase $\mathrm{C}_{4}$ was present in both of the $A$. turicensis strains, while only $13 \%$ of the cluster II strains were positive for the esterase $\mathrm{C}_{4}$ test $(49,50)$. Both $16 \mathrm{~S}$ rRNA sequence and phenotypic data showed that the cluster II strains are identical or closely related to $A$. turicensis. Additional chemotaxonomic and genotypic analyses will be required to confirm the relationship between the two taxa. Since $G$. vaginalis and the $A$. turicensis-like strains are found in the same ecological niche, features that distinguish these two species might be clinically important. $G$. vaginalis strains have fructose-6-phosphate phosphoketolase, $\alpha$-L-glutamyl-L-histidine arylamidase, and L-lysyl-L-serine-4-methoxyarylamidase activities and do not acidify saccharose and xylose, while the $A$. turicensis-like bacteria have the opposite biochemical characteristics.

Strain LMG 14331, the cluster II reference strain, and all of the other cluster II strains have been deposited in the LMG culture collection.

\section{ACKNOWLEDGMENTS}

P.V. is indebted to the National Fund for Scientific Research (Belgium) for a position as a postdoctoral research fellow. M.V., E.M., and K.K. acknowledge the C.E.C. for research contract Bio2-CT94-3098.

E.F. is indebted to B. Sjödén and B. Nordling for technical assistance. We thank all depositors of strains which we examined.

\section{REFERENCES}

1. Amies, C. R., and M. Garabedian. 1963. The bacteriology of human vaginitis. Can. J. Public Health 54:50.

2. Bahaka, D., C. Neut, A. Khattabi, D. Monget, and F. Gavini. 1993. Phenotypic and genomic analyses of human strains belonging or related to Bifidobacterium longum, Bifidobacterium infantis, and Bifidobacterium breve. Int. J. Syst. Bacteriol. 43:565-573.

3. Blackwell, A., A. R. Fox, I. Philips, and D. Barlow. 1983. Anaerobic vaginosis (non-specific vaginitis): clinical, microbiological and therapeutic findings. Lancet ii:1379-1381.

4. Boustouller, Y. L., A. P. Johnson, and D. Taylor-Robinson. 1986. Detection of a species-specific antigen of Gardnerella vaginalis by Western blot analysis. J. Gen. Microbiol. 132:1969-1973.

5. Costas, M. 1992. Classification, identification, and typing of bacteria by the analysis of their one-dimensional polyacrylamide gel electrophoretic protein patterns, p. 351-408. In A. Chambrach, M. J. Dunn, and B. J. Radola (ed.), Advances in electrophoresis, vol. 5. VCH Verlagsgesellschaft, Weinheim, Germany.

6. Criswell, B. S., J. H. Marston, W. A. Stenback, S. H. Black, and H. L. Gardner. 1971. Haemophilus vaginalis 594, a Gram-negative organism? Can. J. Microbiol. 17:865-869.

7. Criswell, B. S., W. A. Stenback, S. H. Black, and H. L. Gardner. 1972. Fine structure of Haemophilus vaginalis. J. Bacteriol. 109:930-932.

8. Csángó, P. A., N. Hagen, and G. Jagars. 1983. Characterization of Gardnerella vaginalis by gas chromatography. Scand. J. Infect. Dis. Suppl. 40:19-22.

9. De Rijk, P., Y. Van De Peer, S. Chapelle, and R. De Wachter. 1994. Database on the structure of large ribosomal subunit RNA. Nucleic Acids Res. 22: 3495-3501.

10. Dunkelberg, W. E., and I. McVeigh. 1969. Growth requirements of Haemophilus vaginalis. Antonie van Leeuwenhoek J. Microbiol. Serol. 35:129145 .

11. Edmunds, P. N. 1960. Haemophilus vaginalis: morphology, cultural charac- 
ters and viability. J. Pathol. Bacteriol. 79:273-284.

12. Edmunds, P. N. 1960. The growth requirements of Haemophilus vaginalis. J. Pathol. Bacteriol. 80:325-335.

13. Edmunds, P. N. 1962. The biochemical, serological and haemagglutinating reactions of "Haemophilus vaginalis." J. Pathol. Bacteriol. 83:411-422.

14. Fox, G. E., J. D. Wisotzkey, and P. Jurtshuk. 1992. How close is close: $16 \mathrm{~S}$ rRNA sequence identity may not be sufficient to guarantee species identity. Int. J. Syst. Bacteriol. 42:166-170.

15. Garabedian, M. S. 1969 . A study of Haemophilus vaginalis Gardner and Dukes. Can. J. Med. Technol. 31:144-150.

16. Gardner, H. L., and C. H. Dukes. 1955. Haemophilus vaginalis vaginitis: a newly defined specific infection previously classified as 'nonspecific' vaginitis. Am. J. Obstet. Gynecol. 69:962-976.

17. Gavini, F., and A. Khattabi. Unpublished data

18. Gavini, F., A.-M. Pourcher, C. Neut, D. Monget, C. Romond, C. Oger, and D. Izard. 1991. Phenotypic differentiation of bifidobacteria of human and animal origins. Int. J. Syst. Bacteriol. 41:548-557.

19. Giesendorf, B. A. J., W. Quint, M. Henkens, H. Stegeman, F. A. Huf, and H. Niesters. 1992. Rapid and sensitive detection of Campylobacter spp. in chicken products using the PCR. Appl. Environ. Microbiol. 58:3804-3808.

20. Greenwood, J. R., and M. J. Pickett. 1980. Transfer of Haemophilus vaginalis Gardner and Dukes to a new genus, Gardnerella: G. vaginalis (Gardner and Dukes) comb. nov. Int. J. Syst. Bacteriol. 30:170-178.

21. Gutell, R. R., B. Weiser, C. R. Woese, and H. F. Noller. 1985. Comparative anatomy of 16S-like ribosomal RNA. Prog. Nucleic Acid Res. Mol. Biol. 32:155-216.

22. Holst, E., P. A. Mårdh, and I. Thelin. 1984. Recovery of anaerobic curved rods and Gardnerella vaginalis from the urethra of men, including male heterosexual consorts to female carriers, p. 173-178. In P. A. Mårdh and D. Taylor-Robinson (ed.), Bacterial vaginosis. Almqvist and Wiksell, Stockholm.

23. Jantzen, E., B. P. Berdal, and T. Omland. 1980. Cellular fatty acid composition of Haemophilus species, Pasteurella multocida, Actinobacillus actinomycetemcomitans and Haemophilus vaginalis (Corynebacterium vaginale). Acta Pathol. Microbiol. Scand. 88:89-93.

24. Jukes, T. H., and C. R. Cantor, 1969. Evolution of protein molecules, p 21-132. In H. N. Munro (ed.), Mammalian protein metabolism. Academic Press, New York.

25. Karison, U., D. F. Dwyer, S. W. Hooper, E. R. B. Moore, K. N. Timmis, and L. D. Eltis. 1993. Two independently regulated cytochromes P-450 in Rhodococcus rhodochrous strain that degrades 2-ethoxyphenol and 4-methoxybenzoate. J. Bacteriol. 175:1467-1474.

26. Krohn, M. A., S. L. Hillier, and D. Eschenbach. 1989. Comparison of methods for diagnosing bacterial vaginosis among pregnant women. J. Clin. Microbiol. 27:1266-1271.

27. Lane, D. J. 1991. 16S/23S sequencing, p. 115-175. In E. Stackebrandt and M Goodfellow (ed.), Nucleic acid techniques in bacterial systematics. John Wiley, Chichester, United Kingdom.

28. Lapage, S. P. 1961. Haemophilus vaginalis and its role in vaginitis. Acta Pathol. Microbiol. Scand. 52:34-54.

29. Lapage, S. P. 1974. Haemophilus vaginalis Gardner and Dukes 1955, p. 368-370. In R. E. Buchanan and N. E. Gibbons (ed.), Bergey's manual of determinative bacteriology, 8th ed. The Williams \& Wilkins Co., Baltimore.

30. Leopold, S. 1953. Heretofore undescribed organism isolated from the genitourinary system. U.S. Armed Forces Med. J. 4:263-266.

31. Moss, C. W., and W. E. Dunkelberg. 1969. Volatile and cellular fatty acids of Haemophilus vaginalis. J. Bacteriol. 100:544-546.

32. Mullis, K. B., and F. Faloona. 1987. Specific synthesis of DNA in vitro via a polymerase-catalyzed chain reaction. Methods Enzymol. 155:335-350.

33. O'Donnell, A. G., D. E. Minnikin, M. Goodfellow, and P. Piot. 1984. Fatty acid, polar lipid and wall amino acid composition of Gardnerella vaginalis.
Arch Microbiol. 138:68-71.

34. Olsen, G. J., N. Larsen, and C. R. Woese. 1991. The Ribosomal RNA Database Project. Nucleic Acids Res, 19:2017-2021.

35. Park, C. H., M. Fauber, and C. B. Cook. 1968. Identification of Haemophilus vaginalis. Am. J. Clin. Pathol. 49:590-593.

36. Piot, P., E. Van Dyck, P. Godts, and J. Vanderheyden. 1982. The vaginal microbial flora in non-specific vaginitis. Eur. J. Clin. Microbiol. 1:301-306.

37. Piot, P., E. Van Dyck, M. Goodfellow, and S. Falkow. 1980. A taxonomic study of Gardnerella vaginalis (Haemophilus vaginalis) Gardner and Dukes 1955. J. Gen. Microbiol. 119:373-396.

38. Pot, B., P. Vandamme, and K. Kersters. 1994. Analysis of electrophoretic whole-organism protein fingerprints, p. 493-521. In M. Goodfellow and A. G. O'Donnell (ed.), Modern microbial methods. Chemical methods in prokaryotic systematics. J. Wiley and Sons, Ltd., Chichester, United Kingdom.

39. Reyn, A., A. Birch-Andersen, and S. P. Lapage. 1966. An electron microscope study of thin sections of Haemophilus vaginalis (Gardner and Dukes) and some possibly related species. Can. J. Microbiol. 12:1125-1136.

40. Sadhu, K., P. A. G. Domingue, A. W. Chow, J. Nelligan, N. Cheng, and J. W. Costerton. 1989. Gardnerella vaginalis has a Gram-positive cell-wall ultrastructure and lacks classical cell-wall lipopolysaccharide. J. Med. Microbiol. 29:229-235.

41. Saiki, R. K., D. H. Gelfand, S. Stoffel, S. J. Scharf, R. Higuchi, G. T. Horn, K. B. Mullis, and H. A. Erlich. 1988. Primer-directed enzymatic amplification of DNA with a thermostable DNA polymerase. Science 239:487-490.

42. Scardovi, V. 1986. Section 15. Irregular nonsporing gram positive rods Genus Bifidobacterium Orla-Jensen 1924, p. 1418-1434. In P. H. A. Sneath, N. S. Mair, M. E. Sharpe, and J. G. Holt (ed.), Bergey's manual of systematic bacteriology, vol. 2. The Williams \& Wilkins Co., Baltimore.

43. Spiegel, C. A., D. A. Eschenbach, R. Amsel, and K. K. Holmes. 1983. Curved anaerobic bacteria in bacterial (nonspecific) vaginosis and their response to antimicrobial therapy. J. Infect. Dis. 148:817-822.

44. Thomason, J. L., P. C. Schreckenberger, W. N. Spellacy, L. J. Riff, and L. J. LeBeau. 1984. Clinical and microbiological characterization of patients with nonspecific vaginosis associated with motile, curved anaerobic rods. J. Infect. Dis. 149:801-809.

45. Vandamme, P., E. Falsen, R. Rossau, B. Hoste, P. Segers, R. Tytgat, and J. De Ley. 1991. Revision of Campylobacter, Helicobacter, and Wolinella taxonomy: emendation of generic descriptions and proposal of Arcobacter gen. nov. Int. J. Syst. Bacteriol. 41:88-103.

46. Vandamme, P., M. Vancanneyt, B. Pot, L. Mels, B. Hoste, D. Dewettinck, L Vlaes, C. Van Den Borre, R. Higgings, J. Hommez, K. Kersters, J.-P. Butzler, and H. Goossens. 1992. Polyphasic taxonomic study of the emended genus Arcobacter with Arcobacter butzleri comb. nov. and Arcobacter skirrowii sp. nov., an aerotolerant bacterium isolated from veterinary specimens. Int. J. Syst. Bacteriol. 42:344-356.

47. Woese, C. R. 1987. Bacterial evolution. Microbiol. Rev. 51:221-271.

48. Woese, C. R., R. Gutell, R. Gupta, and H. F. Noller. 1983. Detailed analysis of the higher-order structure of $16 \mathrm{~S}$-like ribosomal ribonucleic acids. Microbiol. Rev. 47:621-669.

49. Wüst, J., G. Martinetti Lucchini, J. Lüthy-Hottenstein, F. Brun, and M. Altwegg. 1993. Isolation of gram-positive rods that resemble but are clearly distinct from Actinomyces pyogenes from mixed wound infections. J. Clin. Microbiol. 31:1127-1135.

50. Wüst, J., S. Stubbs, N. Weiss, G. Funke, and M. D. Collins. 1995. Assignment of Actinomyces pyogenes-like (CDC coryneform group E) bacteria to the genus Actinomyces as Actinomyces radingae sp. nov. and Actinomyces turicensis sp. nov. Lett. Appl. Microbiol. 20:76-81.

51. Zinneman, K., and G. C. Turner. 1963. The taxonomic position of 'Haemophilus vaginalis' (Corynebacterium vaginale). J. Pathol. Bacteriol. 85:213-219. 